\title{
De prijs van de Zuidas
}

AUTEURS M erijn O udenampsen, J ustus Uitermark \& J esper van Loon

FOTOGRAFIE Chris Shoreflyer \& J esper van Loon

Bedrijfsleven en politiek waren jarenlang eensgezind: op de grens van de Amsterdamse stadsdelen Zuid en Buitenveldert moest een nieuwe toplocatie - de Zuidas - gerealiseerd worden met een voor Nederland ongekende ruimtelijke kwaliteit. $\mathrm{Nu}$ is er echter een impasse in de besluitvorming.

Het is de lente van 2006. Grimbert Rost van Tonningen, een populaire spreker en adviseur van het N ederlandse bedrijfsleven, geeft een presentatie over de toekomst van de Nederlandse economie. Rost van Tonningen presenteert twee scenario's. Op één sheet staat de Zuidas afgebeeld met het woord 'innovatie' ernaast. $0 p$ de volgende sheet wandelt een traditioneel gekleed ouder koppel over de Zaanse Schans: het 'museum' scenario. In het eerste scenario "geldt Nederland binnen Europa als toplocatie voor het bedrijfsleven", in het tweede scenario "leiden wij Amerikaanse, Indiase en Chinese toeristen langs onze kunstschatten tegen een bescheiden fooi." Om de boodschap kracht bij te zetten staat er met hoofdletters "WELVAART" bij het eerste plaatje en "ARM OEDE" bij het tweede. Het is alles of niets, erop of eronder, aan de Zuidas of op klompen. Het contrast zegt veel over de emotionele economie van megaprojecten. Aan de ene kant bestaat er de angst om achter te blijven, om de economische wedloop te verliezen van andere Europese steden en opkomende grootmachten als China en India. Aan de andere kant is er de hoop dat megaprojecten de overgang naar een nieuwe periode van vooruitgang en innovatie markeren.

Binnen de voorstelling van Rost van Tonningen is er geen ruimte voor twijfel: de overheid moet zwaar investeren in het optuigen van toplocaties. Voor de Zuidas zou dit betekenen dat de gemeente Amsterdam kiest voor het zogenaamde dokmodel, waarbij wegen en rails onder de grond worden gebracht. De extra ruimte die zo wordt gecreëerd, wordt volgens de plannen gebruikt om het absolute topsegment van de kantorenmarkt te bedienen. In de flanken van de Zuidas kunnen bovendien duizenden woningen worden gerealiseerd. Het risico zou bovendien afgedekt worden door private partijen te laten participeren.
O m zeker te zijn dat de overheid geen risico's neemt die de markt niet aandurft, nam de Amsterdamse gemeenteraad in 2007 een motie aan van PvdA'er Bouwe O lij waarin werd vastgelegd dat het plan alleen doorgaat als ook private partijen deelnemen. En die wilden dat graag doen. De markt had immers zelf gekozen voor de Zuidas. "De Zuidas ís de markt," aldus de directeur van het Projectbureau Zuidas in 2006. Volgens verantwoordelijk wethouder Maarten van Poelgeest zijn de risico's van het project te verwaarlozen. O nlangs nog beweerde hij dat er "weinig projecten in Nederland zijn waar[van] het risico zo beperkt is." Hij ziet zelfs ruimte om een aanzienlijk percentage sociale woningen te creëren en vermoedt dat de feitelijke kosten veel lager zullen zijn dan de huidige ramingen. Een prachtige kantoorlocatie met sociale woningen zonder risico: het is een aanlokkelijk perspectief voor zowel bestuurders als bedrijfsleven. Inmiddels is echter duidelijk dat de keuze voor het dokmodel verre van triviaal is.

\section{Twijfels}

Al vanaf het begin stelden critici de vraag of het wel nuttig of noodzakelijk is om grootschalige investeringen te doen in een gebied dat op eigen kracht al een stormachtige ontwikkeling doormaakt. Het Centraal Planbureau becijferde in 2003 dat het dokmodel een verlies van ongeveer een miljard zal opleveren. De Zuidas zal bovendien vooral bedrijvigheid van elders aantrekken en weinig nieuwe werkgelegenheid genereren. Met de overname en toekomstige ontmanteling van de ABN AMRO bank valt een van de grote trekkers van het project weg. O ok Van den Ende wil zijn theater uiteindelijk toch niet vestigen aan de Zuidas. De private financiers die de Zuidas altijd stilzwijgend hadden gesteund, lieten onlangs ook van zich horen. Ze zien het niet zitten dat de overheid een deel van ruimte wil gebruiken voor sociale woningen, en ze eisen dat hun risico's gelimiteerd worden. De meest recente dreun voor de Zuidas zijn geruchten over vastgoedfraude aan de Zuidas. Tegen ten minste één notaris is inmiddels een tuchtrechtelijk onderzoek ingesteld.

Politieke voorstanders van de Zuidas laten zich vooralsnog niet uit het veld slaan. Olij, hetzelfde gemeenteraadslid dat eerder private financiering als voorwaarde zag voor de realisatie van het dokmodel, 
pleitte onlangs op de voorpagina van dagblad Het Parool voor een publieke alleingang. Wethouder Van Poelgeest onderzoekt momenteel "terugvalopties" om het dokmodel te realiseren zonder gelijkwaardige deelname van private financiers. Het lijkt erop dat de Amsterdamse politici hun keuze al gemaakt hebben, en ook de rijksoverheid is nog altijd voorstander van het dokmodel. De vraag is niet óf het project gerealiseerd wordt, maar hoe.

De ongunstige ontwikkelingen van de laatste jaren zouden volgens AGORA aanleiding moeten zijn voor bezinning. Nu het duidelijk is dat de keuze voor het dokmodel niet vanzelfsprekend is, ontstaat ruimte voor een open discussie waarbij zowel voorstanders als tegenstanders kunnen worden verleid om echt in debat te gaan. Behalve een uitwisseling van standpunten is dit nummer dan ook vooral een gezamenlijk pleidooi voor meer reflexiviteit. Reflexiviteit veronderstelt dat de auteurs zich niet alleen of hoofdzakelijk ingraven in cijfers en berekeningen, maar de Zuidas plaatsen binnen een breder geografisch en historisch kader. Het is dan ook duidelijk dat een discussie over de Zuidas nooit over het dokmodel alleen kan gaan. De Zuidas staat model voor een bepaald type stadsontwikkeling waarbij grote investeringen in hoopgevende projecten een sleutelrol vervullen.

De Zuidas wordt door voorstanders gezien als een innovatie op het gebied van stedelijke ontwikkeling, niet alleen door haar schaalg rootte en uitstraling, maar ook door de publiekprivate samenwerking. De Zuidas fungeert als een toekomstbeeld voor stedelijke ontwikkeling in Nederland. Megaprojecten elders in Europa, zoals het Potsdamer Platz in Berlijn, Canary Wharf in Londen en La Défense in Parijs vervullen een vergelijkbare rol. De ontwikkeling van dit soort grootschalige prestige- projecten past in een internationale beleidstrend, waarin steden actief proberen hun economische concurrentiepositie te versterken. De hoeveelheid kapitaal aan infrastructuur en onroerend goed die men de komende decennia bij de Zuidas wil investeren, is daarmee verre van slechts een Amsterdamse aangelegenheid. Steden zijn wereldwijd verwikkeld in een logica van onderlinge concurrentie en steken elkaar naar de kroon met ambitieuze bouwplannen. Het is onderdeel van een omslag in het ruimtelijke beleid van de klassieke territoriale verevening en evenredige spreiding van overheidsinvesteringen naar strategische concentratie van middelen op locaties en in sectoren die op internationaal vlak kunnen concurreren.

Met de groeiende populariteit van megaprojecten is er echter tegelijkertijd ook steeds meer kritiek in de internationale literatuur. De grootschaligheid en complexiteit van megaprojecten gaat vaak gepaard met grote risico's. Critici wijzen op tegenvallende opbrengsten en kostenoverschrijdingen, waardoor de projecten een onverwacht zware wissel trekken op publieke gelden. Vaak blijkt dat uiteindelijk slechts een kleine elite profiteert van maatregelen die in het publieke belang worden genomen. Geograaf Erik Swyngedouw spreekt in dit verband van negatieve herverdeling: juist de meest welvarende groepen en sectoren profiteren van overheidsinterventies. Swyngedouw is ook een van de meest uitgesproken critici van de besluitvorming rond megaprojecten. Hij stelt dat allerlei reguliere mechanismen voor democratische controle worden uitgeschakeld onder het mom van "uitzonderlijke omstandigheden". Die kritiek lijkt ook op te gaan voor de Zuidas, aangezien veel van de planvorming achter gesloten deuren plaatsvindt om te voorkomen dat vertrouwelijke bedrijfsinformatie op straat komt
Met de klok mee: Canary Warf (Londen), Potsdamer Platz (Berlijn), La Défense (Parijs) en de Zuidas (Amsterdam).

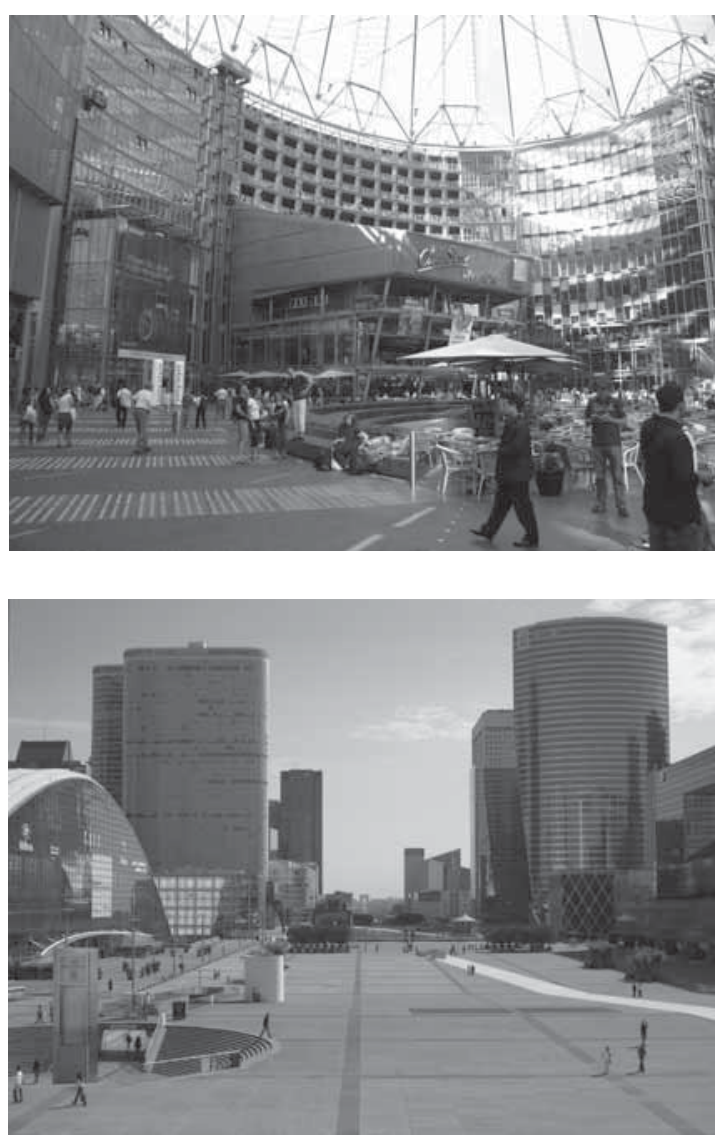
te liggen. Alle reden dus om het debat open te breken.

\section{De Zuidas in perspectief}

O $m$ de Zuidas in internationaal perspectief te plaatsen, begint dit themanummer met een interview met de Deense hoogleraar Bent Flyvbjerg over zijn onderzoek naar megaprojecten in meer dan twintig landen. Volgens Flyvbjerg is de functie van de private financiering bij dit soort projecten die van een lakmoesproef: "Als niemand zijn privékapitaal in een project wil investeren, is dat misschien een goede reden om het niet te bouwen." Hij bekritiseert 'machers' die per se hun stukje geschiedenis willen schrijven in weerwil van de risico's en oppositie. Ondanks dat hij in zijn onderzoek vond dat rationele besluitvorming rond megaprojecten zelden voorkomt - hij spreekt van list en bedrog, premoderne reflexen en tribale neigingen - acht hij de tijd rijp voor een nieuw model waarin transparantie en de betrokkenheid van de 'civil society' essentieel zijn.

Waar Flyvbjerg de nadruk legt op transparantie en het belang van democratische besluitvorming, wijst Gerard Wigmans, docent aan de Technische Universiteit Delft, op de fundamentele onzekerheden van stadsontwikkeling onder de huidige economische omstandigheden.

Snelle marktfluctuaties $d$ wingen steden tot een flexibele opstelling, en onzekerheden zorgen ervoor dat ontwikkeling per definitie meer speculatief wordt. Dat geldt niet alleen voor overheden, maar ook voor bedrijven.

Stan Majoor toont zich in zijn bijdrage een groot voorstander van de ontwikkeling van het megaproject Zuidas. J uist omdat hij grote kansen ziet voor een gedurfde stedelijke ontwikkeling pleit hij voor politisering van de besluitvorming. Hij ziet de huidige impasse als een kans om de plannen rond de Zuidas te radicaliseren. In plaats van jarenlang door te steggelen en te polderen over de kosten en opbrengsten, zou gekozen moeten worden voor een wervend plan: bouw de torens hoger, versterk het stedelijke karakter, verbreed het economisch profiel en organiseer publieke prijsvragen en participatie. Politisering is een integraal onderdeel van de strategie van radicalisering en noodzakelijk om de legitimiteit van de miljardeninvestering te waarborgen.

Een bescheidener variant van de Zuidas wordt voorgesteld door Geurt Keers en Rob de Wildt van RIGO Research en Advies. Zij pleiten voor het dijkmodel in plaats van het dokmodel en een verruiming van het plangebied, zodat de kosten en risico's beperkt blijven. Bij dit model is bovendien een flexibele vorm van planning mogelijk. Daartoe moeten bestuurders echter wel kritisch durven zijn

ten opzichte van de ingeslagen weg.

J os Gadet van de Amsterdamse dienst Ruimtelijke O rdening grijpt terug op de ontwikkeling van de IJ oevers, het vorige Amsterdamse megaproject, dat mislukte. Hij vergelijkt de koers van het megaproject Zuidas met die van een mammoettanker: eenmaal op gang gekomen is die moeilijk van richting te veranderen. De dynamische stedelijke economie vereist volgens $G$ adet een flexibele en kleinschalige benadering. Die benadering heeft zich volgens hem al meer dan bewezen bij de succesvolle herontwikkeling van de IJ oevers.

De drie laatste artikelen van het themagedeelte gaan specifiek in op de onderzoekspolitiek rond megaprojecten: wat is de rol van onderzoekers bij het ontwikkelen of juist bekritiseren van projecten als de Zuidas? Aan de hand van een analyse van de inhoud en ontstaansgeschiedenis van het boek Amsterdam Zuidas European space (2005) beargumenteert sociaal geograaf Martin Cobian dat het academisch onderzoek rond de Zuidas is gevangen in een net van belangenverstrengeling. Cobian stelt dat de auteurs en redacteurs van het boek onderdeel zijn geworden van een neoliberale beleidsagenda en dat zij de keuzes voor de Zuidas trivialiseren in plaats van problematiseren. Willem Salet, een van de redacteuren van het boek en hoogleraar planologie aan de Universiteit van Amsterdam, stelt in zijn repliek dat Cobians "complottheorie" geen hout snijdt en dat hij juist pleit voor publieke financiering van het dokmodel.

Tot slot figureert de Zuidas als illustratie in het pleidooi van Ewald Engelen voor meer reflexiviteit binnen de planologie. Hij stelt dat het belang van ruimtelijke ing repen zwaar wordt overschat. Een "bosje glanzende wolkenkrabbers" acht hij veel minder belangrijk voor economische groei dan bijvoorbeeld onderwijs of een ruimhartig immigratiebeleid. Hij stelt dat planologen en andere plannenmakers de neiging hebben om hun critici te negeren. $0 \mathrm{~m}$ het vertrouwen van burgers terug te winnen is het volgens hem noodzakelijk dat tegenspraak juist wordt georganiseerd.

\section{Tweede kans}

In dit nummer komen voor- en tegenstanders van het dokmodel aan het woord, maar het is niet simpelweg een strijdtoneel van meningen over de vraag of infrastructuur onder of boven de grond moet. De discussie over de Zuidas raakt aan grotere thema's als het democratische gehalte van besluitvorming en de onzekerheden van stedelijke ontwikkeling. Waar wij met dit themanummer voor willen pleiten, is dat de discussie over de Zuidas tegemoet getreden wordt met een open vizier.

De keuze voor het dokmodel wordt veelal gepresenteerd als de enige logische beslissing in een context van groeiende internationale concurrentie of überhaupt niet publiekelijk verantwoord. Door de reeks van tegenslagen is duidelijk geworden dat de keuze voor het Zuidas Dok niet vanzelfsprekend is. Dat geldt voor het bedrijfsleven en dat zou zeker ook moeten gelden voor politici. Zo bezien krijgt het debat over de Zuidas door de huidige impasse een tweede kans. Die kans moeten politici grijpen om nu wél publiekelijk rekenschap te geven van alle voordelen, nadelen en risico's. Dat veronderstelt dat mogelijke alternatieven serieus worden bekeken. Het gaat tenslotte om een enorme investering op een zeer strategische locatie. Als het megaproject Zuidas wordt gerealiseerd, dan moeten we ten minste weten wie daarover heeft beslist, wat de prijs is en wie die prijs betaalt.

Merijn O udenampsen (merijn.oudenampsen@gmail.com) is gastredacteur van AGORA en als onderzoeker verbonden aan de J an van Eyck Academie. J ustus Uitermark (j.I.uitermark@ uva.nl) is redactieadviseur van AGORA en als onderzoeker verbonden aan de Amsterdam School of Social science Research, Universiteit van Amsterdam. J esper van Loon (jespervanloon@gmail.com) is hoofdredacteur van AGORA. 